Novikov, S. /Vol. 2 Num. 3: 4 - 13 / July - december 2020

ISSN Version Web On line: 2711-2454 - DOI: https://doi.org/10.46502/issn.2711-2454/2020.3.1 http://www.economicsjournal.info/index.php/edu/index

Received: July 20, 2019 - Accepted: september 10, 2019

\title{
Influence of innovative factors on the development process of modern multicomponent economic systems
}

Оптимизация трудовых процессов на инновационных предприятиях России

Influencia de factores innovadores en el proceso de desarrollo de sistemas económicos multicomponentes modernos

\author{
Sergey V. Novikov ${ }^{1}$ \\ https://orcid.org/0000-0001-6921-1760 \\ elibrary.ru: https://elibrary.ru/author_profile.asp?id=807011 \\ https://www.scopus.com/authid/detail.uri?authorId=57192318711
}

\begin{abstract}
The article is devoted to the development of methods for the development of modern economic systems, taking into account the influence of various groups of innovative factors. The structural elements of the innovative economy and features of the stability of modern economic systems are revealed, and the main types of stability and ways to increase it are determined. The object of study is multicomponent economic systems are industrial enterprises that are directly affected by various innovative development factors. It has been determined that the increase in scientific and technical information through its acquisition in the production process involves the modernization of production and advanced training of workers, which in turn leads to a change in the factors of production. In Russia, the problem of investing in the innovation sector of the economy is now very urgent and is associated with a number of reasons: absence or weak development of the innovation infrastructure; distrust of potential investors in Russia and enterprises in its regions; need for significant modernization of the country's economy, technical and technological re-equipment of enterprises; lack of sectoral funding (especially R\&D), etc. There is the technique that allows effectively carrying out various planning and innovative development processes at high-tech enterprises in modern economic conditions. It has been established that product technological innovations due to more efficient use of equipment, materials and partial changes in technology, make it possible to obtain an improved product.
\end{abstract}

Keywords: economic systems, innovative economy, innovative activity of enterprises, public-private partnership, innovative planning, high-tech enterprises.

${ }^{1} \mathrm{PhD}$ in Economics, Associate Professor, Head of Institute of Engineering Economics and Humanities, Moscow Aviation Institute (National Research University), Moscow, Russia. 


\section{Economics Journal-}

\section{Аннотация}

Статья посвящена разработке методики развития современных экономических систем с учетом влияния различных групп инновационных факторов. Раскрываются структурные элементы инновационной экономики, особенности устойчивости современных экономических систем, а также определяются основные виды устойчивости и способы ее повышения. Объектом изучения являются многокомпонентные экономические системы - промышленные предприятия, испытывающие на себе непосредственное воздействие различных инновационных факторов развития. Определено, что прирост научно-технической информации посредством еe приобретения в производственном процессе предполагает модернизацию производства и повышение квалификации работников, что в свою очередь приводит к изменению факторов производства. В России проблема инвестирования инновационного сектора экономики сейчас очень актуальна и связана с рядом причин: отсутствием или слабым развитием инновационной инфраструктуры; недоверием потенциальных инвесторов к России и предприятиям в ее регионах; необходимостью существенной модернизации экономики страны, технического и технологического перевооружения предприятий; нехваткой отраслевого финансирования - особенно сферы НИОКР и т.д. Предлагается методика, позволяющая эффективным образом осуществлять различные процессы планирования и инновационного развития на высокотехнологичных предприятиях в современных экономических условиях. Установлено, что продуктовые технологические инновации за счет более эффективного использования оборудования, материалов, частичного изменения технологии, позволяют получить усовершенствованный продукт.

Ключевые слова: экономические системы, инновационная экономика, инновационная деятельность предприятий, частно-государственное партнерство, инновационное планирование, высокотехнологичные предприятия.

\section{Resumen}

El artículo está dedicado al desarrollo de métodos para el desarrollo de sistemas económicos modernos, teniendo en cuenta la influencia de varios grupos de factores innovadores. Se revelan los elementos estructurales de la economía innovadora, las características de la sustentabilidad de los sistemas económicos modernos y se determinan los principales tipos de sustentabilidad y las formas de incrementarla. El objeto de estudio son los sistemas económicos multicomponente: empresas industriales que se ven directamente afectadas por diversos factores de desarrollo innovadores. Se ha determinado que el aumento de la información científica y técnica a través de su adquisición en el proceso productivo implica la modernización de la producción y la formación avanzada de los trabajadores, lo que a su vez conduce a un cambio en los factores de producción. En Rusia, el problema de invertir en el sector de la innovación de la economía es ahora muy urgente y está asociado con una serie de razones: la ausencia o el débil desarrollo de la infraestructura de innovación; desconfianza de los posibles inversores en Rusia y las empresas de sus regiones; la necesidad de una importante modernización de la economía del país, reequipamiento técnico y tecnológico de las empresas; falta de financiación sectorial, especialmente I + D, etc. Se propone una técnica que le permite llevar a cabo de manera efectiva varios procesos de planificación y desarrollo innovador en empresas de alta tecnología en condiciones económicas 


\section{Economics Journal-}

modernas. Se ha establecido que las innovaciones tecnológicas de los productos debido a un uso más eficiente de los equipos, materiales, cambios parciales en la tecnología, permiten obtener un producto mejorado.

Palabras clave: sistemas económicos, economía innovadora, actividad innovadora de las empresas, asociación público-privada, planificación innovadora, empresas de alta tecnología.

\section{Introduction}

The study of modern aspects inherent in the development of complex social and economic systems in Russia leads to the conclusion that stability and long-term economic growth of the national economy is impossible without a comprehensive implementation of the innovation cycle. The structural composition of the cycle of innovation includes the following: organization and conduct of research; technology creation and development processes; organization of industrial production; entry and subsequent promotion of the created goods to the market; sale of innovative products. The practical implementation of the elements included in the innovation cycle has largely contributed to the formation of a close connection between science and real economy. The organization of such close cooperation made it possible to increase the intensity and effectiveness of various studies, improved the indicators of the stability of commercial structures to the norms of law in force in the country and in the field of intellectual property protection, etc. (Dzhuraev, Akhmatova \& Teshaeva, 2015). It should be noted that almost any innovative economic activity that is carried out within the close boundaries of the designated economic system always has a certain level of impact on it. Consequently, the force and the vector of impact are in direct proportion to the current state in which the chosen economic system arrives at a given moment. Modern economic conditions that have developed in Russia, including the formed trend for the development of domestic enterprises, import substitution in a number of key industries, as well as a consistent increase in the level of competitiveness of Russian-made goods, etc., served as the main groups of factors contributing to innovative development (Kolosova, Sazonov \& Vnuchkov, 2018).

\section{Theoretical basis}

At the moment, the vast majority of economic systems are in a certain transitional state, for example, the economic systems of developed high-tech countries are currently in a state of transition from an information society to an innovative one. We try to understand the concept of an innovative economy, and for this we will consider it from two semantic aspects. In the broadest sense of the concept, it is a certain combination of elements of technological structures and cycles of scientific and technological progress. In a narrow sense, the concept of an innovative economy is understood, as a rule, as a certain organization, in which the production basis is made up of high-tech products, as well as advanced materials and technologies and the corresponding social, organizational and economic structures (Astapov, 2005).

Innovation activity is a type of activity that implies the search and implementation of innovations in order to increase assortment, improve product quality, technology and organization of production. The main function of innovation is the function of change. I. Schumpeter noted five typical changes (Danilochkina, Sazonov \& Zinchenko, 2018): 


\section{Economics Journal-}

1. Use of new technology, technological processes or market support for production (purchase - sale).

2. Introduction of products with new properties.

3. Using new raw materials.

4. Changes in the organization of production and its material and technical support.

5. Emergence of new sales markets.

To increase the current indicator of innovative activity of domestic enterprises and their subsequent achievements of the key indicators indicated in the business plans in terms of innovative development, it is necessary to revise the measures in force in today's Russian economy to support and develop innovations. In the course of the study, factors influencing the innovative development of enterprises were identified and combined into groups.

First group. Factors determining the level of current innovative development, in terms of educational, scientific and technological aspects (Kuntzman, 2018):

- presence of a certain innovative potential of universities, which includes obtaining patents for various scientific developments, publications of conducted research, not only in leading Russian scientific journals, but also in foreign journals included in scientometric databases, such as Scopus, Web of Science (WoS), etc.

Second group. Factors determining the level of current innovative development in terms of regulatory and legal aspects (Maslova, 2019):

- degree of development of innovative activity, which includes the presence of strategies for the development of key industries, laws on the organization of innovative activities, targeted programs necessary for the effective development of innovations;

- availability of mechanisms aimed at assistance in obtaining patents, copyright protection, as well as improving the situation in the field of intellectual capital management of organizations.

Third group. Factors determining the level of current innovative development in terms of the organizational aspect (Porokhovsky, 2015):

- possibility of introducing modern methods necessary for the effective management of various production processes (including the use of mechanisms for the digitalization of a number of processes) in modern high-tech enterprises;

- application of outsourcing model, for example, for enterprises operating in the aviation industry.

Fourth group. Factors determining the level of current innovative development in the production aspect (Rakhimova, Kunanbaeva \& Goncharenko, 2019):

- development of quality management systems for products manufactured by enterprises;

- availability of production and technological base that fully meets all the highest modern requirements for security and productivity, which is capable of functioning in a complex information environment at the industry level. 


\section{Economics \\ Journal-}

An innovative economy is based on a certain change in the combinations of various components embedded in the structure of production forces, i.e. for example, the implementation of the process of transition to a comprehensively automated type of production, as well as the direct development of products of a science-intensive nature. Of course, the innovative economy also includes mechanisms aimed at increasing various immaterial forms of society's wealth such as inventions, discoveries and, of course, rationalization, which ultimately leads to an increasing role of intellectual capital (Ministerio de Desarrollo EconómicoFederación Rusa, 2020). Analysis and assessment of the characteristics presented above, as well as other processes in the field of innovation, allows correctly understanding and studying the main groups and types of existing patterns and directions associated with transition processes in a modern economy.

\section{Theoretical basis}

Modern economic systems have to a certain indicator of stability. Its concept in relation to economic systems means that the latter have a certain ability that allows them not only to achieve certain results (which have a low degree of possible deviations), but also to use unique recovery mechanisms if the system is influenced by negative factors. The simplest option for the stability of almost any economic system, of course, is the state of equilibrium, in which it stay, for a sufficiently long period, subject to the condition that it is not affected by any disturbing effect. We consider several types of stability (Razin, 2016):

1. Appearance of stability. This type is characterized by a certain degree of stability present in a certain economic environment, which has a certain degree of impact on a high-tech enterprise, while, in order to achieve a certain level of equilibrium in it, it is necessary to use management mechanisms throughout the whole country.

2. Internal view of stability. It represents a certain state of the enterprise, in which the overall level of its functioning increases, i.e. take into account changes in the structure of production affecting the types of provided services.

3. Stability with a hereditary appearance. It is characterized by the fact that the enterprise must have some reserves of financial stability, which have been successfully formed over the past several periods, which will allow the enterprise to significantly minimize possible negative changes in the external or internal environment.

4. Financial and economic type of stability. To a certain extent, it can be characterized by a level of financial stability, expressed, for example, in the degree of liquidity of assets, and the presence within the enterprise of the optimal combination of space-time relations.

Ensuring a stability level of development and functioning of an enterprise depends on a certain degree of development of a certain set of factors within the enterprise, such as: degree of flexibility and adaptation, as well as the level of innovation. This means that there is a definite need to organize procedures for planning the development of modern economic systems. For the stability development of planning processes within the enterprise, it is proposed to use the methodology for the formation of mechanisms for the stability and effective development of modern economic systems (Figure 1) (Ukhina, Agafonova \& Polovinkin, 2016). 
In order for economic systems to develop steadily, it is necessary that certain properties of self-organization are present within them, which means that the most general principles and properties can be identified that are characteristic of the elements included in the concept of innovative development (Saybel \& Kosarev, 2018):

1. Economic systems combine the principles of openness and disequilibrium, i.e. there is a very large range of potential changes, which directly depends on the degree of changes occurring in the environment, and it should also be noted that disequilibrium manifests itself due to internal and external contradictions.

2. Stability can be effectively maintained through the use of resources, in other words, there is a certain pattern, which is that the degree of stability of the structure depends on how efficiently the resources are used.

3. Degree of uncertainty plays one of the key roles in innovative development, since the so-called wave character is inherent in economic processes, in other words, a huge number of processes and changes take place in the economy, for example, existing technological structures change or new points of economic growth arise.

4. Economic systems, as a rule, develop unevenly, and often their development depends on certain results obtained from innovative activities that take place within the enterprises themselves. 


\section{- Economics Journal}

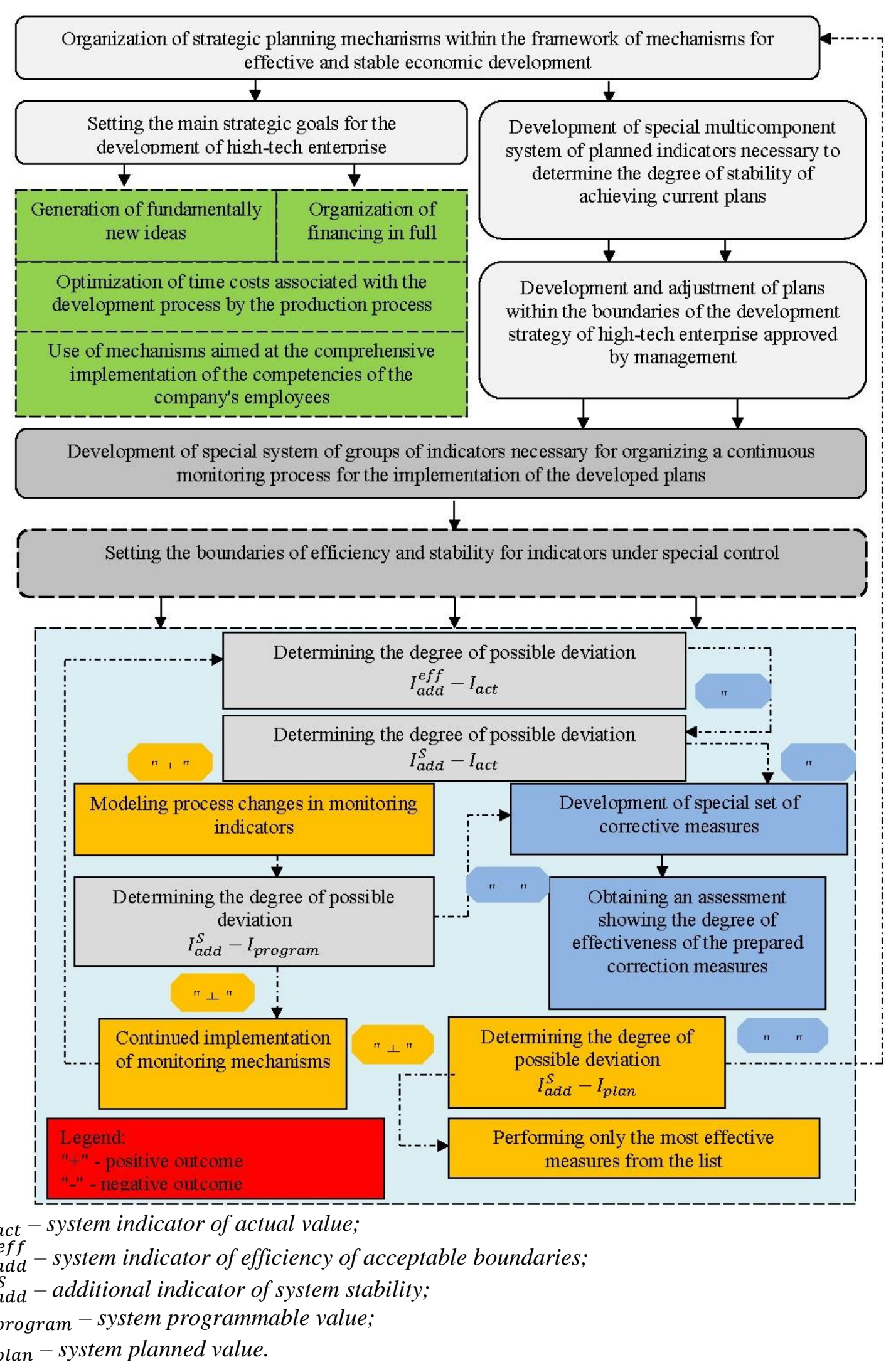

Figure 1. Methodology for the formation of mechanisms for sustainable and effective development of modern economic system at high-tech Enterprise. 


\section{Results}

The problem of investment and innovation is very urgent for the Russian economy, it is interconnected with the underdeveloped capital market. Funding for innovation often comes from the company's own funds, which are limited. As a consequence, this leads to the problem of financing innovation and the involvement and interest of the participants in the process. At the same time, it is necessary to involve not only the commercial sector, research and scientific organizations, but also the state in the process of investing in innovations. State activities can stimulate the growth of innovative activities, increasing the security of transactions and the attractiveness of this type of activity for investment, as well as guarantee the approach to the technological border of the country's economy as a whole, which ultimately will affect economic growth (Teslenko, Digilina \& Kornilova, 2015).

Successful innovation activities of enterprises require cooperation of enterprises with scientific and research organizations, as well as the organization of clusters, whose activities are aimed at further innovative development. To train qualified personnel for innovative activities, appropriate educational institutions (higher education institutions, postgraduate studies and doctoral studies) are needed. The distribution of such establishments across the Russian Federation is uneven. But when considering the number of higher educational institutions and institutions of postgraduate education per population, the distribution of such educational institutions is relatively even, i.e. regardless of location (western or eastern part of the Russian Federation), most regions have the same potential for innovation.

So, investments and innovations are one of the main determining factors of economic growth in any country, as they contribute to the formation of an innovative economy. In Russia, the problem of investing in the innovative sector of the economy is now very urgent. It is associated with a number of reasons: absence or weak development of the innovation infrastructure; distrust of potential investors in Russia and enterprises in its regions; need for significant modernization of the country's economy, technical and technological re-equipment of enterprises; lack of sectoral funding (especially R\&D), etc. This contributes to the need to develop a comprehensive state investment policy for the most innovative industries of the economy, education and science.

\section{Discussion}

Innovative activity of the enterprise is a certain set of measures aimed at the creation, acquisition, development and distribution of new or modernized types of products, services, technologies, raw materials, methods of organizing production and management. Innovation activity involves a whole range of scientific, technological, organizational, financial and commercial activities, which lead to innovation. When acquiring certain information, the enterprise compares the marginal usefulness of information and the marginal costs associated with its direct acquisition. The marginal utility of information can increase, decrease or be constant, as the marginal cost of acquiring it. If the marginal utility is shown to be higher than the marginal cost, it is certainly beneficial for the enterprise to buy additional units of information (Shutkov, 2019). 


\section{Economics \\ Journal-}

Information, being heterogeneous good, changes the operation of the law of marginal utility. The increase in scientific and technical information through its acquisition in the production process involves the modernization of production and the improvement of the qualifications of workers, which in turn leads to a change in the factors of production. If the marginal cost is higher than the marginal utility of information, it is not profitable for the enterprise to acquire information, but in this case, the costs of acquiring information are shifted to the total costs of the enterprise, which ultimately increase, reducing the gross profit of the enterprise. In this case, not every business can afford to purchase information. The decision to purchase additional units of information will not depend on the branch of the enterprise: in modern conditions, enterprises in industry, agriculture, services, trade, etc. are forced to acquire information for effective activity.

In a competitive environment, enterprise may occupy a certain market niche and not be interested in acquiring information. Enterprise, possessing a certain amount of information, makes a product (or service) that, despite the presence of competitors, may be in demand. Neither industry, nor enterprise's competitive environment or even favorable relation between the marginal cost of information and the marginal cost of acquiring will not be the main reasons for acquiring information. The main reason for the acquisition of information can be attributed to the desire of the enterprise, which can be dictated by various reasons. One of the main reasons can be attributed to the presence of a sufficient amount of financial resources for the company to acquire information (Chechina, 2015).

\section{Conclusions}

The positive impact of innovation on the life cycle of a technology is aimed at a more efficient use of this technology, increase in its life. The negative impact will primarily affect the life of the technology and additional costs aimed at improving or developing an alternative technology. But, on the other hand, the negative impact of innovation accelerates the replacement of the used technology, stimulates the development (or acquisition) of a new, more advanced technology at the moment, which allows to increase productivity, to produce a better product; which, in turn, requires additional investments in the development and in the acquisition of new equipment or technology.

In the economic development of any country, innovations play an important role, allowing the enterprise to apply various strategies that allow developing more new products and advanced technological methods of their production, which allows them to successfully compete in the market. Process technological innovations are aimed at mastering improved production methods that allow the use of new equipment and new technologies in order to obtain a new product. Product technological innovations due to more efficient use of equipment, materials, partial changes in technology, allow to get an improved product (Fedotova, Ilyasov \& Tserenova, 2018). 


\section{References}

Astapov, K. L. (2005). Features of the development of economic systems in modern conditions. Moscow University Bulletin. Series: Economics, 4, 65-85.

Chechina, O. S. (2015). Factors of innovative development of the sectoral economic system. The successes of modern natural science, 1(2), 280-282.

Danilochkina, N. G., Sazonov, A. A., \& Zinchenko, A. S. (2018). Modified multicomponent organizational and economic mechanism of enterprise management based on intellectual capital. Bulletin of the Moscow State Regional University. Series: Economics, 4, 58-66.

Dzhuraev, A. T., Akhmatova, M. E., \& Teshaeva, M. D. (2015). Modern characteristics of the types of economic systems. Young scientist, 12, 409-413.

Fedotova, G. V., Ilyasov, R. Kh., \& Tserenova, B. I. (2018). Assessment of indicators of forecast of socio-economic development of Russia for 2018-2020. Financial analytics: problems and solutions, 11(4), 368-386.

Kolosova, V. V., Sazonov, A. A., \& Vnuchkov, Yu. A. (2018). Study of the main components of the innovative potential of a machine-building enterprise at the present stage of development of the Russian economy. Bulletin of the Moscow State Regional University. Series: Economics, 3, 87-93.

Kuntzman, A. A. (2018). Building an effective enterprise architecture as a prerequisite for adapting to the digital economy. Innovation economy issues, 8(4), 753-770.

Maslova, V. M. (2019). Digital transformation - new HR management processes. Economic systems, 12(1), 50-55.

Ministerio de Desarrollo Económico Federación Rusa (2020). Forecast of social and economic development of the Russian Federation for 2018 and for the planning period of 2019 and 2020. Available at: https://www.economy.gov.ru/material/directions/makroec/prognozy_socialno_ekonomi cheskogo_razvitiya/prognoz_socialno_ekonomicheskogo_razvitiya_rossiyskoy_federac ii_na_2018_god_i_na_planovyy_period_2019_i_2020_godov.html

Porokhovsky, A. A. (2015). The economic system of modern Russia: ways and goals of development: monograph. Moscow: Faculty of Economics, Moscow State University named after M.V. Lomonosov.

Rakhimova, S. A., Kunanbaeva, K. B., \& Goncharenko, L. P. (2019). Development of innovation-oriented business structures. Economic systems, 12(3-4), 84-96.

Razin, A. V. (2016). Factors influencing the innovative development of the Russian economy. Actual problems of aviation and astronautics, 12, 1052-1054.

Saybel, N. Yu., \& Kosarev, A. S. (2018). Transformation factors of the socio-economic system. International research journal, 12(66), 58-63.

Shutkov, A. A. (2019). Problems of sustainable and innovative development of the economy in the digital age. Economic systems, 12(3-4), 139-141.

Teslenko, I. B., Digilina, O. B., \& Kornilova, O. A. (2015). On the issue of creating an innovative model for the country's development on the basis of public-private partnership. Modern problems of science and education, 2(1).

Ukhina, A. V., Agafonova, M. S., \& Polovinkin, I. S. (2016). Investment and innovation factors of economic growth. Scientific Review. Economic sciences, 2, 197-199. 